\title{
RULES ON MONETARY POLICY AND INTERNATIONAL IMPERFECT SUBSTITUTIONS OF ASSETS
}

\section{TAUFIQ CARNEGIE DAWOOD}

Facultas Ekonomi dan Bisnis, Universitas Syiah Kuala, Banda Aceh

This paper revisits and extend discussions which evaluate the impact of different rules on monetary policy. Rules on one which excludes or includes stability of the exchange rate as an objective of monetary policy making, with currency mismatch existence as given, on the fluctuations of major economic variables. In this paper I develop a financial accelerator model with financial intermediary consistent with currency mismatch, and assume imperfect international substitutability of assets. This paper found that the variation of rule of monetary policy considered in the analysis produces variations in the fluctuations of the macroeconomic variable. However the impact of the different monetary policy rules on the stability of the macroeconomic variables is shock dependent.

Keywords: Shocks to Risk Premium Shocks, Economic Variations, DSGE, Policy Rules 


\section{INTRODUCTION}

An important goal for numerous countries in the world is economic stability. Monetary policy is one policy instrument to attain such goal. However conducting correct monetary policy is not always obvious. An issue that can effect the behavior and performance of policy making, in particular monetary policy making, in small economies which are open to international flows of trade and financial flows are the problem of currency mismatch.

Many developing countries which opened up their capital accounts face the problem of currency mismatch. If their banks borrow from abroad or from global financial markets, the borrowing terms must be specified in currency of foreign countries. Thus repayments of interest and principal to the international lenders must be made in currency abroad.But these funds are lent out to domestic firms and individuals, and are repaid in currency of the domestic economy. But markets for forward transactions for the currency of the domestic economy may not exist.If it does, the level of trading in the market may be "shallow" and the level of lliquidity is still low. Thus making hedging against risk of sudden changes of the rates of exchange intricate and exorbitant. (Eichengreen and Hausman, 1999, Calvo (2006)).

There exists discussions of the effect of currency mismatch on rules of monetary policy choices that uses uses a Dynamic Stochastic General Equilibrium Model with Balance Sheet Effects/Financial Accelerator Model of Bernanke et.al. (1999).

But the conclusion of these discussions has not yet found its accord.

One of the view proposed by Cespedes et.al. (2004), made an argument in which a regime of flexible rates of exchange, coupled with rules which targets inflationary changes offers higher level of robusteness to the macroeconomy to withstand shocks from abroad, relative to rules which attempts on fixing the rates of exchange of the economy. On the otherhand Choi and Cook (2004) found that a rule which fixes the rates of exchange fixed exchange rate rule that can make the banks' balance sheets stable, offer larger robustness than do a rule which uses the domestic interest rate with the objective of targeting domestic inflation.

It is noted that the above papers do not explicitly consider capital flows in their analysis. In particular the aforementioned papers assumes perfect international substitutability of assets. Liu and Spiegel (2013) had found that by assuming imperfect substitutability of assets and capital controls, monetary policy aimed at "smoothing" the exchange rate is optimal. It should be noted that an important feature of business cycles and monetary policy responses in small open economies is that they are highly influenced by international capital flows (Kaminsky and Reinhart, 1998).

I revisit and extend the above arguments. I develop a financial accelerator model consistent with currency mismatch, and assume imperfect international substitutability of assets.

To the author's best account, this analysis is the first scholary work which uses models to analyze policy making with the existence of currency mismatch and balace sheet effect.

Then I explore the variations in oscilations of imporatnt variabels of the macroeconomy by comparing policy rules that places large weights the stability of the real rates of exchange and rules on policy that place small encumbrances on the real rates of exchange rate robustness.

\section{THE MODEL}

This study develops an infinite horizon small open economy model with financial intermediation and a financial accelerator mechanism of Bernanke.et.al (1999), and I assume that the home country in the international market for capital acts as a borrower in the net sense.

The banks of the domestic economy provide credit to households by purchasing bonds which has single period duration which is denominated in home country's currency issued by households. These banks finance their lending in excess of their net worth by borrowing from foreign investors/creditors.

There are several assumption which I impose to the model. The first assumption is that there exist currency mismatch for the home country. Currency mismatch can be defined as follows. Suppose that the ome country faces a world interst 
rate, and due to the issue of "original sin" domestic banks must borrow and redeem its foreign debt and interest, from issuing one period bonds, in the currency of foreign countries (for example US\$). The second assumption imposed in this study is that there does not exist markets for instruments to hedge against risk of changes in the foreign exchange for the home country's currency. The implication is that home country's banks do not cover theirselves against foreign currency risk by going into contract such as using instruments of markets of futures for foreign currency. Third, household and non-financial firms cannot borrow in the international capital market, fourth, Assume that there is imperfect international substitutability between domestic and foreign assets, fifth to ensure the existence of a unique positive stochastic discount factor, and because of the previous assumption, assume that (generalized) Uncovered Interest Rate Parity holds and the international financial market is complete, sixth, banks can hold two types of assets, domestic assets issued by households and foreign assets. Seventh, households owns and rent labor and capital to firms.

\section{Households}

Assume a typical household in the economy which selects a combination of leisure and consumption, and each combination of lesssierue gives a level of utility to the household. It is also assumed that the producing firm is owned by the typical households. Income of the typical household is generated from the supply of capital and labor the production process, and from profits residual of the producer of intermediate output products and importer of intermediate goods firms. Moreover the typical household In addition, towards the end of each period $t$, the household amass debt.

To model the typical household this study employs an amended form of Dib (2011) by adding two assumptions to the model. The first assumption that households are accumulating debt with the borrower pays the contemporaneous domestic interest rate for its debt. This assumption is in line with the assumption that the economy is a net debtor. The second assumption, households does not hold foreign bonds or borrow from abroad.
With these assumption at hand, the optimization problem of the household can be written as follows.

$U_{t}=E_{n} \sum_{t a 0}^{\infty} \beta^{\prime}\left\{\frac{\gamma a_{t}}{\gamma-1} \ln \left(C_{t}^{\frac{y-1}{\gamma}}+b^{\frac{1}{t}}\left(\frac{M_{t} t}{P_{t}}\right)^{\frac{\gamma-1}{\gamma}}\right)+\eta \ln \left(1-L_{d}\right)\right\}, \beta \equiv(0,1)$

Subject to the following budget constraint:

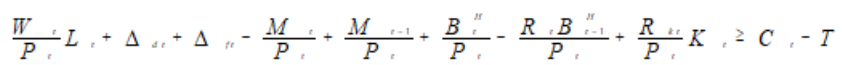

Denote $B_{t}$ as the domestic one period bonds denominated in domestic currency issued by household and sold to banks at the end of period $\mathrm{t}, W_{t}$ as the wage and $\Delta_{d t}, \Delta_{f t}$, as real profit from ownership of firms, $C_{t}$ is the real consumption of final goods $Z_{t}, B_{t-1}$ is the t- 1 bonds redeemed by households from banks with paying the gross interest $R_{t}$ and $R_{k t}$ serving as capital rental/returns.

The condition necessary for the typical household optimization problem is the following:

$$
\lambda_{t}=\frac{a_{t} C_{t}^{-\frac{1}{\gamma}}}{C_{t}^{\frac{\gamma-1}{\gamma}}+b_{t}^{\frac{1}{\gamma}} m_{t}^{\frac{\gamma-1}{\gamma}}}
$$

The first order condition for consumption and holding real money balances is.

$$
\lambda_{t}-\beta E_{t}\left(\frac{P_{t} \lambda_{t+1}}{P_{t+1}}\right)=\frac{a_{t} C_{t}^{-\frac{1}{\gamma}}}{C_{t}^{\frac{\gamma-1}{\gamma}}+b_{t}^{\frac{1}{\gamma}} m_{t}^{\frac{\gamma-1}{\gamma}}}
$$

The substitution intra-period among consumption with work forthe household is as follows:

$$
\lambda_{t} \frac{W_{t}}{P_{t}}=\frac{\eta}{L_{t}}
$$

And the substitution across time between and purchasing capital and consumption is as the following:

$$
\psi\left(\frac{\boldsymbol{k}_{t+1}}{\boldsymbol{k}_{t}}\right)+1=\beta E_{t}\left[\frac{\lambda_{t+1}}{\lambda_{t}}\left(\frac{\boldsymbol{R}_{k+1}}{\boldsymbol{P}_{t+1}}+1 \overline{(\sigma)} \delta+\frac{\psi}{2}\left(\frac{\boldsymbol{k}_{t+2}^{2}}{\boldsymbol{k}_{t+1}^{2}}-1\right)\right)\right]
$$

Denote $R_{t}$ as the gross rate of return of domestic risk free asset. The inter-temporal substitution from issuing domestic bonds is:

$$
1=\beta E_{t}\left[\frac{P_{t} \lambda_{t+1} R_{t+1}}{P_{t+1} \lambda_{t}}\right]=\beta E_{t}\left[\frac{\lambda_{t+1} R_{t+1}}{\pi_{t+1} \lambda_{t}}\right]
$$

Denote $\delta$ and $q_{t}$ being the rate of depreciation for capital and the real rate of exchange respectively. 


\section{Banking Sector}

The main economic agent in this model is the bank sector. We define the setting for the banking sector as follows. Assume that this economy is small relative to the rest of the world and it is open to international trade and international flows of capital. Assume further that, given the global rates of interest, this economy is a debtor in the net sense. Assuming asymmetric information between domestic households with international investors/lenders such that domestic households do not have access to issuing bonds to foreign creditors but can issue and sell one period bonds in domestic currency to domestic banks (domestic bonds which has single period duration which is denominated in home country's currency). However the banks has access to a complete asset market which can be traded internationally.

Assume that there are one unit measure of banks owners which are neutral towards risk, and each are prone to risk which are idiosyncratic in nature and are observed but only imperfectly. Assume that banks have access to foreign borrowing and a complete assets market which can be traded internationally. And assume that the bank can then intermediate these funds to domestic households by purchasing domestic bonds which has single period duration which is denominated in home country's currency issued by domestic households.

In excess to its net worth, the bank borrows from foreigners by issuing and selling domestic one period bonds denominated in foreign currency to foreign investors/lenders. The banks then use these funds to either lend in the domestic economy in domestic currency by purchasing domestic one period bonds denominated in domestic currency or purchase foreign one period bonds. Assume that foreign investors/lenders will only purchase domestic assets issued by domestic banks in the form of domestic one period bonds denominated in foreign currency. Thus we have the setting of currency mismatch.

Because the domestic banks can also purchase foreign one period bonds, thus the bank has two types of asset; domestic bonds which has single period duration which is denominated in home country's currency issued by domestic households and foreign one period bonds. On the liability side the bank has one type of liability; domestic one period bonds denominated in foreign currency issued by the bank and purchased by foreign investors/lenders. We assume that the domestic banks holds both types of assets in their portfolio. By assuming imperfect substitutability between domestic and foreign assets, assume that there is a portfolio adjustment cost from altering the composition of the portfolio between foreign and domestic assets.

A banker starts at time $t$ with net worth $\boldsymbol{n} \boldsymbol{w}_{\mathrm{t}}$. On the period $t$ the banker purchase domestic bonds which has single period duration which is denominated in home country's currency from households, $b_{t}^{l, h}$ which in return provide a rate of return which are free of risk denoted as $R_{t}$ in domestic currency. In addition banks also choose to purchase one period foreign currency denominated bonds $b_{t}^{l, f}$ which gives non-diversifiable free return in foreign currency of $R_{t}^{*}$. Following Dib (2011) assume that $R_{t}^{*}$ is exogenous and follows a stationary process:

$$
\ln R_{t}^{*}=\left(1-\rho_{r^{*}}\right) \ln R^{*}+\rho_{r^{*}} \ln R_{t-1}^{*}+\varepsilon_{\mathrm{r}^{*} t}
$$

Assume $\rho_{r^{*}} \in(-1,1)$. Denote $R^{*}$ as the steady state foreign interest rate, $\sigma_{r}$ is the standard deviation of $R_{t}^{*}$ and is an i.i.d. $\varepsilon_{\mathrm{r}^{*} t}$ is a standard normally distributed random variable.

To finance this purchase in excess of net worth, the banks issues and sells domestic one period bonds denominated in foreign currency to foreign investors/lenders and convert the proceeds to be in the currency of the home country by using the spot nominal rate of exchange $e_{t}$

Denote $e_{t}$ as the domestic currency price of one unit of foreign currency. Assume that interest rate for the domestic one period bond denominated in foreign currency issued by the bank is $R_{t}^{*}$ which must be paid in foreign currency.

In addition assume that domestic assets are imperfect substitutes for foreign assets and there is a portfolio adjustment cost represented by the parameter $\Omega_{b}$. As a note, by the assumption of imperfect substitutability between foreign and domestic assets, the domestic bank would hold both asset despite the portfolio adjustment cost. 
Specify the debt of the bank, in the form of domestic one period bonds denominated in foreign currency issued by bank "h" and sold to foreign investors, multiplied by adjustment cost in excess of net worth as:

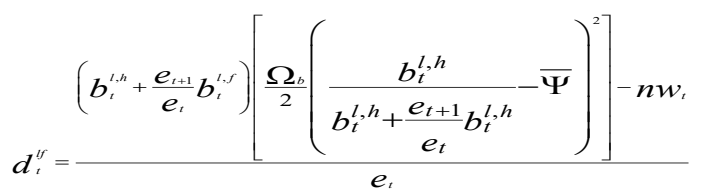

$$
\Psi_{t}=\frac{b_{b t}^{l, h}}{b_{t}^{l, h}+\frac{e_{t+1}}{e_{t}} b_{t}^{l, f}}
$$

The term $\Psi_{t}$ denotes the share of domestic currency bonds to total portfolio held by the bank while $\bar{\psi}$ denotes the steady state share of domestic currency bonds in the portfolio. The term $\frac{e_{t+1}}{e_{b t}}$ is viewed as the domestic currency equiva- $e_{t}$ lent of the foreign bonds held by the bank in their portfolio.

Following Choi and Cook (2004) for the domestic currency lending, denote the banks post one period net revenues in nominal terms which also includes purchase of foreign assets as $\omega_{t+1}^{l}\left(R_{t} b_{t}^{t, h}+\frac{e_{t+1}}{e_{t}} R_{t}^{*} b_{t}^{t, f}\right) \begin{aligned} & \text { evaluated in the currency } \\ & \text { of the home country. De- }\end{aligned}$ note $\omega_{t}^{l}$ as bank l's technology at time t, which are variables that random in nature, and for each of the banks they are independent with probability distribution being lognormal with expected value of 1. Foreign investors/lenders can observe $\omega_{t+1}^{l}$ only with cost of monitoring which equals to the ratio of the banks overall asset $\mu\left[\omega_{t+1}^{\prime}\left(R_{t} b_{t}^{\prime, h}+\frac{e_{t+1}}{e_{t}} R_{t}^{*} b_{t}^{\prime, f}\right)\right]$.

In this paper we assume that the optimization behavior of foreign lenders is exogenous to the economy.

Closely following Carlstrom and Fuerst (1997), the optimal financial contract can be described as follows. The bank chooses the quantity of domestic currency denominated lending (which is equivalent to the amount of domestic one period bonds denominated in domestic currency) $b_{t}^{H}$ and foreign one period bonds $b_{t}^{F}$ prior to the realization of the idiosyncratic risk $\omega_{t}^{l}$, interest rate for domestic currency lending (from purchasing one period bonds denominated in domestic currency), $R_{t}$, interest from purchasing foreign one period bonds $R_{t}^{*}$ which is exogenous and $R_{t}^{d}$ which is the interest rate that the bank must pay in foreign currency when issuing and selling domestic one period bonds in denominated in foreign currency to foreign investors. As in Bernanke et.al. (1999) the interest rate $R_{t}^{d}$ is state contingent to eliminate any aggregate risk to foreign investors.

The implied state contingent minimum efficiency level $\bar{\omega}_{\text {at }}$ which default is avoided is:

$\bar{\omega}_{t+1}^{\prime}\left(\frac{e_{t}}{e_{t+1}}\right)\left(R_{t} b_{t}^{t, i}+\frac{e_{t+1}}{e_{t}} R_{t}^{*} b_{t t}^{t, t}\right)=R_{t}^{d}\left\{\left(b_{t}^{t, h}+\frac{e_{t+1}}{e_{t}} b_{t t}^{t, t}\right)\left[1+\frac{\Omega_{b}}{2}\left(\Psi_{t}-\bar{\Psi}\right)^{2}\right]-N W_{t}\right\}$

Assuming a realized spot rate of exchange in nominal terms $e_{t}$, and for the non-default case, the expected payoff for the bank is the proceeds that it receives from the domestic one period bonds denominated in domestic currency and foreign one period bonds minus the interest paid to foreign investors/lenders from their holding of domestic one period foreign currency denominated bonds which is a multiple of the non-default probability multiplied by the probability of no default.

In the case of default the bank receives nothing. Thus the expected payoff to the banker can be written as:

$$
f\left(\bar{\omega}_{t+1}^{l}\right)\left[R_{t} b_{t}^{l, h}+\frac{e_{t+1}}{e_{t}} R_{t}^{*} b_{b t}^{l, f}\right]
$$

Following Choi and Cook (2004), the ratio of the banker's payoff expectation encompassing the pertinent magnitude of the random variable $\omega$ such that probabilities are positive can be written as:

$$
f(\bar{\omega})=\int_{\bar{\omega}}^{1} \frac{\omega}{1-\underline{\omega}} d \omega-\bar{\omega} \int_{\bar{\omega}}^{1} \frac{1}{1-\underline{\omega}} d \omega
$$

The payoff expectations of creditors in abroad (investors) are payments of interest received net of capital control tax for the example of non-default, or bank's value (net for the cost of liquidization) for example of default and are denoted in the following expression:

$$
g\left(\overline{\boldsymbol{\omega}}_{t+1}^{l}\right)\left[\boldsymbol{R}_{t} \boldsymbol{b}_{t}^{l, h}+\frac{\boldsymbol{e}_{t+1}}{\boldsymbol{e}_{t}} \boldsymbol{R}_{t}^{*} \boldsymbol{b}_{b t}^{l, f}\right]
$$


The fraction of expected payoff encompassing the pertinent magnitude of the random variable $\bar{\omega}$ such that probabilities are positive can be written as:

$$
g(\bar{\omega})=\bar{\omega} \int_{\bar{\omega}}^{1} \frac{1}{1-\underline{\omega}} d \omega+\int_{\underline{\omega}}^{\bar{\omega}} \frac{(1-\mu) \omega}{1-\underline{\omega}} d \omega
$$

This expression is the share of net asset which goes to foreign investors.

To construct the expression for the optimal financial contracting problem we assume the following.

First assume that the bank has adequate power for bargaining in order for gathering residual returns. Second assume constant dollar price of foreign goods. Finally assume that the foreign investors/lender receives average returns in ex post fashion which sums to the risk free rates of interest in foreign currency which assume to be exogenous $R_{t}^{*}$.

The optimal financial contracting problem can be written as follows:

$$
\frac{\operatorname{Max}}{\left\{{\bar{\omega}, b^{l, h}, b^{l, j}}^{l}\right.} E_{t}\left\{f\left(\bar{\omega}_{t+1}^{l}\right)\left(\frac{e_{t}}{e_{t+1}}\right)\left[R_{t} b_{t}^{l, h}+\frac{e_{t+1}}{e_{t}} R_{t}^{*} b_{t}^{l, f}\right]\right.
$$

the necessary conditions can be viewed as a generalized UIP condition. This is because if the portfolio adjustment $\operatorname{cost} \Omega_{b}$ were zero under the assumption of perfect substitutability between foreign and domestic assets, then we get an open economy version of the supply curve of investment finance a.la. Bernanke et.al (1999) where the existence of financial frictions in the form of liability dollarization produces a wedge in the standard UIP condition in the form of a (gross) default risk premium (which in Bernanke et.al (1999) it is signified as being external financing premium). And if the gross premium for the risk of default $\kappa_{t}$ (which is a function of the credit worthiness of the bank) is one (which implies net default risk premium is zero) then this expression would reduce to a standard UIP condition.

As argued in Choi and Cook (2004) assume that the bank productivity $\omega$ is independent of any individual characteristic of the bank. With this assumption define the aggregate constraint of all banks in the economy as:

$\left.+\left(\lambda_{t+1}\right)\left\{g\left(\bar{\omega}_{t+1}^{l}\right)\left(\frac{e_{t}}{e_{t+1}}\right)\left[R_{t} b_{t}^{l, h}+\frac{e_{t+1}}{e_{t}} R_{t}^{*} b_{t}^{l, f}\right]-R_{t}^{*}\left\{\left(b_{t}^{l, h}+\frac{e_{t+1}}{e_{t}} b_{t}^{l, f}\right)\left[\frac{\Omega_{b}}{2}\left(\frac{b_{t}^{t, h}}{b_{t}^{l, h}+\frac{e_{t+1}}{e_{t}} b_{t}^{l, f}}-\bar{\Psi}\right)^{2}\right]+n w_{t}\right\}\right\}\right\}$

The necessary condition of the banker's optimizing problem is

$$
\begin{aligned}
& E_{t}\left\{\left\{\left[\frac{1}{\kappa_{t}}\right]\left[R_{t}\left(\frac{e_{t}}{e_{t+1}}\right)-R_{t}^{*}\right]\right\}\right. \\
& =\Omega_{b}\left(\Psi_{t}-\bar{\Psi}\right)\left[\left(R_{t}^{*}-\frac{e_{t+1}}{e_{t}} R_{t}^{*}\right) \frac{\left(\Psi_{t}-\bar{\Psi}\right)}{2}-\frac{e_{t+1}}{e_{t}} R_{t}^{*}\left(\frac{b_{t}^{l, h}+b_{t}^{l, f}}{\Psi_{t}}\right)\right]
\end{aligned}
$$

Denote $\kappa_{t} \equiv \frac{\lambda_{t}}{f\left(\bar{\omega}_{t+1}^{t}\right)+\lambda g\left(\bar{\omega}_{t+1}^{l}\right)}$ as the gross um of banks which following Choi and Cook (2004) depends on the credit worthiness (and implying it depends also on the leverage ratio) of the bank.

$$
E_{t}\left\{\left[f^{\prime}\left(\bar{\omega}_{t+1}^{l}\right)+\lambda_{t+1} g^{\prime}\left(\bar{\omega}_{t+1}^{l}\right)\right]\left(\frac{e_{t}}{e_{t+1}}\right)\left[R_{t} b_{t}^{l, h}+e_{t} R_{t}^{*} b_{b t}^{l, f}\right]\right\}=0
$$

The first of the above expressions for

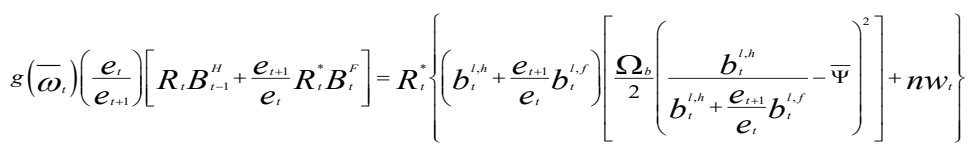

In addition the first order conditions in aggregate form can also be written as:

$$
\begin{aligned}
& E_{t}\left\{\left\{\left[\frac{1}{\boldsymbol{\kappa}_{t-1}}\right]\left[R_{t-1}\left(\frac{\boldsymbol{e}_{t-1}}{\boldsymbol{e}_{t}}\right)-\boldsymbol{R}_{t-1}^{*}\right]\right\}\right. \\
& =\Omega_{b}\left(\Psi_{t}-\bar{\Psi}\right)\left[\left(R_{t}^{*}-\frac{e_{t+1}}{e_{t}} R_{t}^{*}\right) \frac{\left(\Psi_{t}-\bar{\Psi}\right)}{2}-\frac{e_{t+1}}{e_{t}} R_{t}^{*}\left(\frac{B_{t}^{\prime \prime}+B_{t}^{F}}{\Psi_{t}}\right)\right]
\end{aligned}
$$

Define the real exchange rate as $s_{t}=\frac{e_{t} P_{t}^{*}}{P_{t}}$ . For convenience redefine the aggregate first order condition and the proportion of the banks' portfolio held in domestic assets to be in real terms as follows. 
$E_{t}\left\{\left[\frac{1}{\boldsymbol{K}_{t+1}}\right]\left[\boldsymbol{R}_{t}\left(\frac{\boldsymbol{S}_{t}}{\boldsymbol{S}_{t+1}} \frac{\pi_{t+1}^{*}}{\pi_{t+1}}\right)-R_{t}^{*}\right]\right\}=R_{t}^{*} \boldsymbol{\Omega}_{b}\left(\frac{B_{t}^{F}}{B_{t}^{H}+S_{t} B_{t}^{F}}-\bar{\psi}\right)$

$$
\begin{aligned}
& \boldsymbol{\aleph}_{t+1}=\frac{E_{t}\left(\lambda_{t+1}\right)}{f\left(\bar{\omega}_{t+1}^{l}\right)+\lambda_{t+1} g\left(\bar{\omega}_{t+1}^{l}\right)} \\
& \frac{\Psi_{t}}{\boldsymbol{P}_{t}} \equiv \boldsymbol{\psi} .
\end{aligned}
$$

Following Carlstrom and Fuerst (1997) and Bernanke et.al. (1999), assume that bankers are risk neutral with constant subjective discount factor and that a fraction $1-\gamma$ of bankers die in every period and in the final period they will consume all of their net worth. Using this assumption and redefine the debt of the bank in terms of the domestic currency using the redefinition in equation (12), we can aggregate the one period bonds issued and sold by domestic banks to foreign investors (which is also the supply of one period bonds in foreign currency issued by domestic banks) as in the following difference equation:

$d_{t}=\frac{S_{t+1}}{S_{t}} \frac{\pi_{t+1}}{\pi_{t+1}^{*}}\left(b_{t}^{H}+S_{t} b_{t}^{F}\right)\left[1+\frac{\Omega_{b}}{2}\left(\psi_{t}-\bar{\psi}\right)^{2}\right]-\frac{S_{t+1}}{S_{t}} \frac{\pi_{t+1}}{\pi_{t+1}^{*}} \Gamma R_{t}^{k}\left(\frac{b_{t-1}^{H}}{\pi_{t}}+\frac{S_{t-1}}{\pi_{t}} b_{t-1}^{F}\right)+\frac{S_{t+1}}{S_{t}} \frac{\pi_{t+1}}{\pi^{*}} \Gamma R_{t}^{*} \frac{d_{t-1}}{\pi_{t}}$ falls. For a given level of total do-

This is basically the amount of borrowing in foreign exchange taken by the banks from the international capital market. Because the model assumes only banks borrow from abroad thus this is also equals to the total stock of the country's foreign debt.

Following Choi and Cook (2004), and denote the survival rate of the bankers to the next period as $\Gamma$, the net worth of the banks can be written as:

$$
N W_{t}=\Gamma f\left(\bar{\omega}_{t}\right)\left[R_{t} B_{t-1}^{H}+S_{t-1} R_{t}^{*} B_{t-1}^{F}\right]
$$

Following Corsetti, Dedola and Leduc (2011), the assumption of imperfect substitutability between domestic assets and foreign assets imply that the demand function for domestic one period bonds denominated in foreign currency issued by banks (in terms of domestic currency) is upward sloping with respect to interest rate differentials. Using a modified version of Liu and Spiegel (2013), the demand for the one period bonds issued by banks is denoted with the following:

$$
\begin{gathered}
\frac{D_{t}}{A_{t} \pi_{t}}=E_{t}\left\{\left[\frac{1}{\boldsymbol{K}_{t+1}}\right]\left[R_{t}\left(\frac{S_{t}}{S_{t+1}} \frac{\pi_{t+1}^{*}}{\pi_{t+1}}\right)-R_{t}^{*}\right]\right\}-R_{t}^{*} \Omega_{b}\left(\frac{B_{t}^{F}}{B_{t}^{H}+S_{t} B_{t}^{F}}-\bar{\psi}\right) \\
\boldsymbol{K}_{t+1}=\frac{E_{t}\left(\lambda_{t+1}\right)}{f\left(\overline{\boldsymbol{\omega}}_{t+1}^{l}\right)+\lambda_{t+1} g\left(\overline{\boldsymbol{\omega}}_{t+1}^{l}\right)}
\end{gathered}
$$
the ratio of debt-to-net worth (lever-

By assuming $\mathrm{f}^{\prime}(\mathrm{)}>0$, this is interpreted as that an increase in the interest rate differential would increase the foreign demand for domestic one period bond denominated in foreign currency issued by the banks. In the view of the foreign investors, this implies that domestic one period bonds are imperfect substitutes for foreign bonds with similar maturity.

\section{Discussion of net worth and default premium}

Now we establish the relation between nominal exchange rate, net worth and the default premium of the bank. This relationship is embedded in equations (6), (8) and (12). Note from equation (8) that all variables except $\bar{\omega}_{t}$ and $e_{t}$ are predetermined. Suppose the nominal exchange rate depreciates (which implies $e_{t}$ rises). According to equation (9) and the expression for $g\left(\bar{\omega}_{t+1}\right)$, this is coupled by an increase in $\bar{\omega}_{t}$. From equation (6) and (8), a rise in $\bar{\omega}_{t}$ requires a fall in $f\left(\bar{\omega}_{t+1}\right)$ and thus by equation (12) the net worth of the bank age ratio) rises. Following Choi and Cook (2004), around the steady state, the default risk premium $\boldsymbol{\kappa}_{t}$ is an increasing function of the leverage ratio, thus $\kappa_{t}$ rises. In sum, a depreciation of the nominal exchange rate increases the default risk premium for the bank.

With the establishment of the relationship between net worth of the bank with the default risk premium through the change in the exchange rate, we can define the financial accelerator model for the banking sector. Following Bernanke et.al. (1999) and modifying it, the financial accelerator model for the banking sector can be defined by the following equations.

The first equation is the gross return of portfolio of the bank $R^{k}$ which can be defined as follows.

$$
R_{t}^{K}=E_{t}\left\{\frac{R_{t} B_{t}^{H}+S_{t+1} R_{t}^{*} B_{t}^{F}}{\left(B_{t}^{H}+S_{t} B_{t}^{F}\right)}\right\}
$$

Denote $S_{t}$ as the real exchange rate.

The relationship between risk premium and net worth can be defined as:

$$
\boldsymbol{\kappa}_{t}=\boldsymbol{E}_{t}\left(\frac{\boldsymbol{R}_{t+1}^{\kappa}}{\boldsymbol{R}_{t+1}^{*}}\right)=\left(\frac{N W_{t+1}}{D_{t+1}}\right)^{-\zeta}
$$


Equations (13) and (15) may be viewed as representing the supply curve for external financing from abroad. Firstly foreign lenders demand the bonds issued by the domestic banks depends on the interest rate differentials. On top of this, following Bernanke et.al. (1999) the foreign lenders (investors) also require a default risk premium to lend to the bank (i.e. to purchase the bonds issued by the banks').

The third equation is the law of motion for the net worth of the banking sector.

In difference equation in can be written as:

$n w_{t}=\Gamma\left\{R_{t}^{K}\left(\frac{b_{t-1}^{H}}{\pi_{t}}+\frac{S_{t-1} b_{t-1}^{F}}{\pi_{t}}\right)-R_{t}^{*}\left(\frac{b_{t-1}^{H}}{\pi_{t}}+\frac{S_{t-1} b_{t-1}^{F}}{\pi_{t}}\right)\left[1+\frac{\Omega_{b}}{2}\left(\Psi_{t-1}-\bar{\psi}\right)^{2}\right]+R_{t}^{*} \frac{n W_{t-1}}{\pi_{t}}\right\}$

\section{The firm}

The model specification in this section follows from Dib (2011). The firms are owned by households. The production sector consists of three sectors. The final goods firms, the domestic intermediate goods firms and the imported intermediate goods firms.

\section{Domestic and imported composite goods}

The composite domestic and imported intermediate goods $\left(Y_{d r} Y_{f,}\right)$ are by combining a continuum of differentiated domestic and imported intermediate goods $\left(Y_{d t}^{(j)}, Y_{f j}(j)\right)$. Denote the successive intermediate good as $\left(P_{d t}(\mathrm{j}), P_{\delta^{\prime}}(j), P_{d r} P_{f}\right)$, profit maximization results into the following demand functions for each goods " $\mathrm{j}$ ” of domestic and imported differentiated goods, the Producer price index (PPI) and Importer Price Index (IPI)

$$
\begin{aligned}
& Y_{d t}(j)=\left(\frac{P_{d t}(j)}{P_{d t}}\right)^{-\theta} Y_{d t} \\
& P_{d t}=\left(\int_{0}^{1} P_{d t}(j) d j\right)^{\frac{1}{1-\theta}} \\
& Y_{n}(j)=\left(\frac{P_{f t}(j)}{P_{f t}}\right)^{-\theta} Y_{n t} \\
& P_{n t}=\left(\int_{0}^{1} P_{f t}(j) d j\right)^{\frac{1}{1-\theta}}
\end{aligned}
$$

\section{The final goods firms}

The final goods firm is perfectly competitive. It aggregates domestic and imported intermediate goods $\left(Y_{d r} Y_{f}\right)$ to produce final goods $Z_{t}$ with following aggregation technology:

$$
Z_{i}=\left[\left(1-\omega_{f}\right)^{\frac{1}{\nu}} Y^{\frac{\nu-1}{\nu}}+\omega_{f}^{\frac{1}{\nu}} Y_{f t}^{\frac{\nu-1}{\nu}}\right]^{\frac{v}{\nu-1}}
$$

The final goods can be used for consumption and investment so that the resource constraint can be written as:

$$
Z_{t}=C_{t}+I_{t}
$$

Profit maximization with respect to equation (20) result in the following demand functions of domestic and imported differentiated goods:

$$
\begin{aligned}
& Y_{d t}=\left(1-\omega_{f}\right)\left(\frac{P_{d t}}{P_{t}}\right)^{-v} Z_{t} \\
& Y_{d t}=\left(\omega_{f}\right)\left(\frac{P_{f t}}{P_{t}}\right)^{-v} Z_{t}
\end{aligned}
$$

The consumer price index is defined as:

$$
P_{t}=\left[\left(1-\omega_{f}\right) P_{d t}^{1-v}+\omega_{f} P_{f t}^{1-v}\right]^{\frac{1}{1-v}}
$$

\section{The domestic intermediate goods producing firms and import intermediate goods firms}

Each domestic intermediate goods producing firms is monopolistically competitive and adjust price according to Calvo (1983) and a fraction of $(1-\phi)$ firms can reset their price, while remaining prices are unchanged. Each firm produce differentiated product by employing labor $L_{t}$ and capital $K_{t}$ from households and using the following technology:

$$
\boldsymbol{Y}_{t}=\boldsymbol{K}_{t}^{\alpha}\left[\boldsymbol{A}_{t} \boldsymbol{L}_{t}\right]^{1-\alpha} \quad, \alpha \in(0,1)
$$

The exogenous technology shock $A_{t}$ evolves according to the following law of motion:

$$
\ln A_{t}=\left(1-\rho_{A}\right) \ln A+\rho_{A} \ln A_{t-1}+\varepsilon_{A t}
$$

The domestic intermediate goods can be used domestically or exported so that

$$
Y_{t}(j)=Y_{d t}(j)+Y_{x t}(j)
$$

The foreign demand for domestic goods are defined as follows.

$$
Y_{x t}(j)=\left(\frac{P_{d t}(j)}{e_{t} P_{t}^{*}}\right)^{-\theta} Y_{x t}
$$

The aggregated foreign demand for domestic exports can be written as:

$$
Y_{x t}=\left(\frac{P_{d t}}{e_{t} P_{t}^{*}}\right)^{-t}=\left(\frac{P_{d t}}{s_{t} P_{t}}\right)^{-\tau}
$$

Foreign price $P_{t}^{*}$ evolves according to the following law of motion: 


$$
\ln \left(\frac{P_{t}^{*}}{P_{t-1}^{*}}\right)=\left(1-\rho_{\pi^{*}}\right) \ln \left(\pi^{*}\right)+\rho_{\pi^{\prime}} \cdot \ln \left(\frac{P_{t-1}^{*}}{P_{t-2}^{*}}\right)+\varepsilon_{\pi^{t}}
$$

Firms chooses price $\bar{P}_{d t}(j)$ to maximize profit subject to equations (17) and (27). Profit maximization yield the following aggregated first order condition:

$$
\begin{aligned}
& \frac{W_{t}}{P_{t}}=(1-\alpha) \frac{Y_{t}(j)}{L_{t}(j)} q_{t} \stackrel{\circ}{P}_{d t} \\
& \frac{R_{k t}}{P_{t}}=\alpha \frac{Y_{t}(j)}{K_{t}(j)} q_{t} \stackrel{\circ}{P}_{d t} \\
& \bar{P}_{d t}(j)=\frac{\theta}{1-\theta} \frac{E_{t} \sum_{t=0}^{\infty}(\beta \phi)^{t} \lambda_{t+1} y_{t+1} q_{t+1}}{\frac{E_{t} \sum_{t=0}^{\infty}(\beta \phi)^{t} \lambda_{t+1} y_{t+1}}{P_{d t+1}}}
\end{aligned}
$$

Define $\stackrel{\circ}{P}_{d t}=\frac{P_{d t}}{P_{t}}$ and denote $q_{t}$ is the Lagrangian multiplier applied to the production function constraint in the profit maximization.

Define the aggregate domestic price index as:

$$
P_{d t}^{1-\theta}=\phi P_{d t-1}^{1-\theta}+(1-\phi) \bar{P}_{d t}^{1-\theta}
$$

\section{Imported Intermediate Goods}

Homogenous intermediate goods are imported by a continuum of $j \in[0,1]$ importers which are of the Calvo (1983) type. A fraction of $(1-\phi)$ firms can reset their price, while remaining prices are unchanged. Firms chooses price $\bar{P}_{f t}(j)$ to maximize profit subject to equation (19). Profit maximization results in the following first order condition.

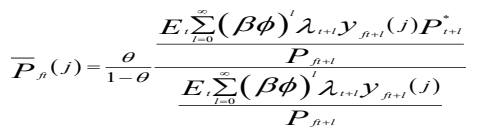

Define the real exchange rate as $S_{t}=\frac{e_{t} P_{t}^{*}}{P_{t}}$.

Define the aggregate import price index as:

$$
P_{f t}^{1-\theta}=\phi P_{f t-1}^{1-\theta}+(1-\phi) \bar{P}_{f t}^{1-\theta}
$$

\section{The Central Bank}

Following Peters (2008) assumes that the small open economy's central bank oversees the performance of the rates of interest in short period terms denoted $R_{t}$, when there is deviancy of of national output production $Y_{t}$, inflation $\pi_{t}$, money supply growth $\mu_{t}$, plus the real exchange rate $s_{t}$ The rule for monetary policy and could be denoted as follows:

$$
\ln \left(\frac{R_{t}}{R}\right)=\rho_{y} \ln \left(\frac{Y_{t}}{Y}\right)+\rho_{\pi} \ln \left(\frac{\pi_{t}}{\pi}\right)+\rho_{\mu} \ln \left(\frac{\mu_{t}}{\mu}\right)+\rho_{s} \ln \left(\frac{S_{t}}{s}\right)+\ln v_{t}
$$

The Steady states are denoted as variables without the time subscripts. The shock to monetary policy shock obeys a lae of motion which is denoted as follows.

$$
\ln v_{t}=\rho_{v} \ln v_{t-1}+\varepsilon_{v t} ; \rho_{v} \in(0,1)
$$

\section{Current account}

The current account for this model implies that the flow of foreign bonds, adjusted for default risk premium of the bank is equal to the difference between the export and import of intermediate goods of the small open economy with the other countries in the world. The current account can be written as follows.

$$
\frac{B_{t}^{F}}{\boldsymbol{K}_{t} R_{t}^{*}}-\frac{B_{t-1}^{F}}{\pi_{t}^{*}}=\frac{\stackrel{\circ}{d t}_{d t} y_{x t}}{S_{t}}-y_{f t}
$$

\section{Conditions of Equilibrium}

With the assumption that all economic agents which are the firms, impoters plus domestic producers and consumers are symetrical, the requirement conditions for equilibrium are the following.

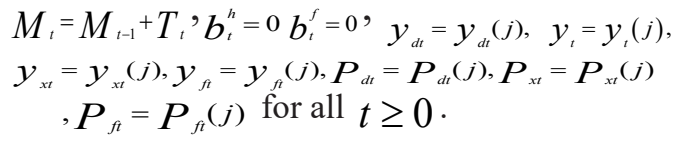

\section{ANALYSIS}

\section{Calibration}

In this study, the paremeters for the model for firms and typical households are calibrated form Peters (2008) for Thailand. Two saperate rules for monetary policy are employed for the analysis at hand. A rule with large encumbrances on the real rates of exchange rate robustness $\left(\rho_{s}\right)$ in the monetary policy rule, and the other rule with small weight. The current analysis sets the magnitude of $\rho_{s}=1.3202223$ for the rule on monetary policy which place lesser encumbrances on the real rates of exchange rate robustness. And this analysis sets the magnitude of $\rho_{s}=4$ for the rule on monetary policy which place greater encumbrances on the real rates of exchange rate robustness.

For the banking sector, this paper employs the following parameter values. The steady state values for portfolio share of domestic bonds of the banks $\Psi_{b}$ follows from Liu and Spiegel (2013) while the parameter value for the survival rate of 
the banker $\Gamma$ and the default risk parameter $\zeta$ follows Bernanke et.al. (1999). The values of the parameters are presented in appendix $\mathrm{C}$.

\section{Impulse response function (IRF)}

In the current paper I analyze impulse response graphs of various variabels of the macroeconomy which are respectively, output of intermediate goods (y), consumption(c), domestic nominal interest rate (r), the real exchange rate (s) and CPI inflation (pi). The shocks considered are monetary policy shocks, technology shocks and foreign price shock. The graphs of the impulse responses are formed for the subsequent two rules of monetary policy considered in this analysis; case one where greater encumbrances is placed on the real rates of exchange rate robustness, while case two places lesser encumbrances on the real rates of exchange rate robustness.

\section{Monetary policy shock}

Consider a positive shock to monetary policy which implies a tightening of the monetary policy stance. With a shock resulting in a monetary policy tightening, domestic interest rate (r) rose and consumption (c) and inflation rate (pi) fell before returning to its steady state level in both cases. Also in both cases the real exchange rate appreciated before going to steady state. The reason for this is that the positive monetary policy shock which result in the increase in the domestic interest rate result in capital inflow, which hence would induce the appreciation of the exchange rate. In addition to this, consumption fell and investment rose. The reason for this result is that due to the rise in the domestic interest rate, this induce substitution away from current consumption towards future consumption, and thus investment (see appendix).

Observing the fluctuations of impulse responses of the macroeconomic variables considered, it can be seen that the changes in consumption, domestic interest rate, and output higher in case 1 than in case 2 . This might indicate that a more stable real exchange rate might provide lower fluctuations of macroeconomic variables in relation to monetary policy shocks.

\section{Technology shock}

Next consider a positive shock to technology. Following a positive shock to technology, consumption (c) and production of intermediate goods (y) rise in the two cases.Inflation fell in both cases. In contrast he real exchange rate and domestic interest rate did not change very much on impact.

In contrast to monetary policy shocks there are no significant differences in the fluctuation of the macroeconomic variables, (Figure 1 and Figure 2).

\section{Shock to foreign inflation}

Finalay observe a positive shock to foreign inflation. With a positive foreign inflation shock, CPI inflation consumption and domestic interest rate rose in both cases.In addition, the real exchange rate appreciated in bot monetary policy rule cases, (Figure 3 and Figure 4).

In relation to the volatility of the macroeconomic variables considered in this analysis, in contrast to shocks to monetary policy, consumption, CPI inflation, and intermediate output production seems to fluctuate less in case 2 then in case 1. While the real exchange rate seems to fluctuate more in case 2 than in case1. Thus this indicate that, with the exception of the real exchange rate, a more flexible exchange rate seems to provide lower volatility of macroeconomic variables for the case of shocks to foreign inflation.

\section{CONCLUSION}

By specifying a financial accelerator model with liability dollarization with balance sheet effect and imperfect international substitutability of assets, it can be observed that there are variations in the volatility of the macroeconomic variable under consideration for the two monetary policy rule cases analyzed in this paper. However the results from this paper seems to indicate that the impact of the two monetary policy rules under consideration in the fluctuations of macroeconomic variables is not symmetric. With monetary policy shocks, a monetary policy rule with a more stable real exchange rate seems to provide greater stability of the macroeconomic variables under consideration. In contrast the same cannot be said for technology shocks and foreign price shocks. 


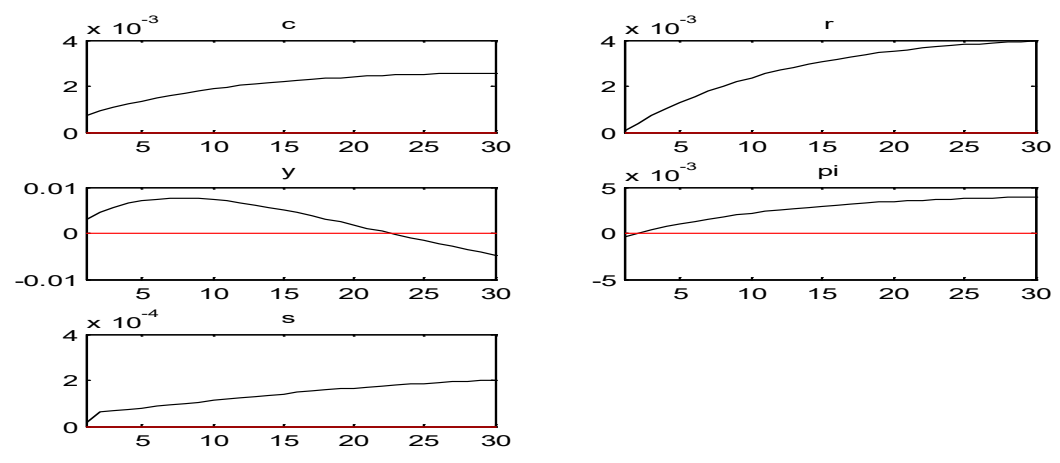

Figure 1. Technology shock (case 1)
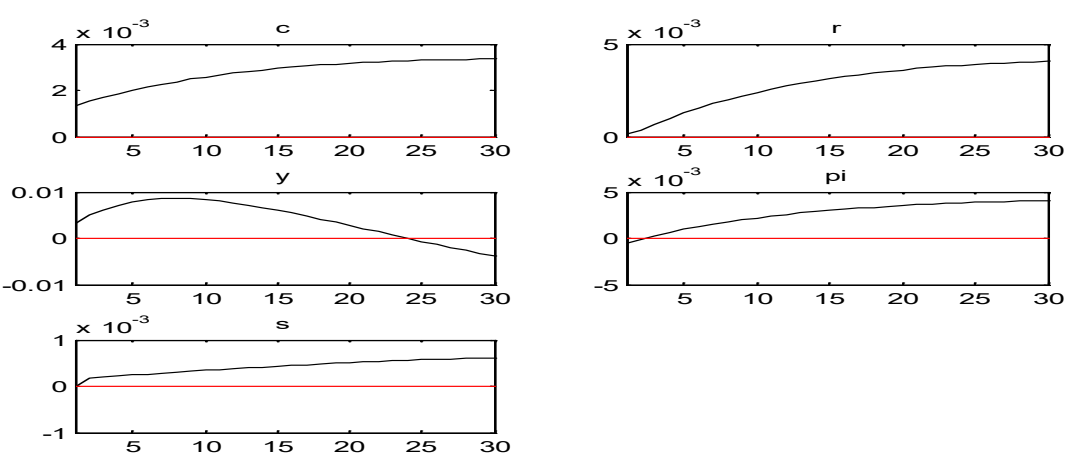

Figure 2. Technology shock (case 2)
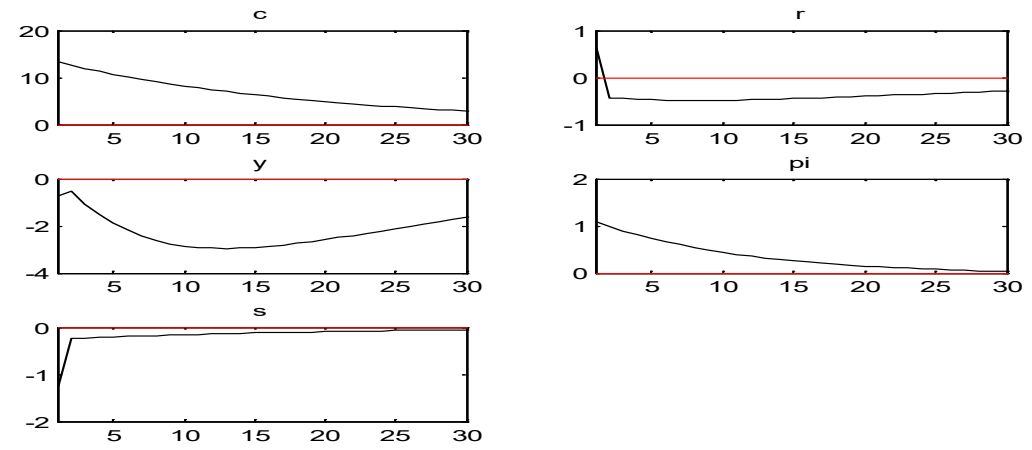

Figure 3. Foreign inflation shock (case 1)
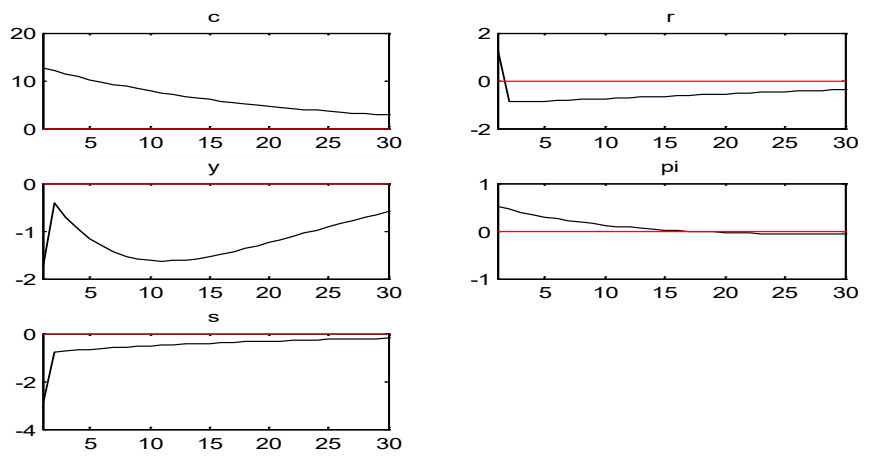

Figur 4. Foreign inflation shock (case 2) 


\section{REFERENCES}

Bernanke, B. S., Gertler, M., \& Gilchrist, S. (1999). The financial accelerator in a quantitative business cycle framework. Handbook of macroeconomics, 1, 1341-1393.

Carlstrom, C. T., \& Fuerst, T. S. (1997). Agency costs, net worth, and business fluctuations: A computable general equilibrium analysis. The American Economic Review, 893-910.

Céspedes, L. F., Chang, R., \& Velasco, A. (2004). "Balance Sheets and Exchange Rate Policy." The American Economic Review 94(4), 1183-193. http://www.jstor.org/stable/3592812.

Calvo, G. A. (1983). Staggered prices in a utility-maximizing framework. Journal of monetary Economics, 12(3), 383-398.

Calvo, G. A. (2006). Monetary policy challenges in emerging markets: Sudden stop, liability dollarization, and lender of last resort (No. w12788). National Bureau of Economic Research.

Choi, W. G., \& Cook, D. (2004). Liability dollarization and the bank balance sheet channel. Journal of International Economics, 64(2), 247-275.

Dib, A. (2011). Monetary policy in estimated models of small open and closed economies. Open Economies Review, 22(5), 769-796.

Eichengreen, B., \& Hausmann, R. (1999). Exchange rates and financial fragility (No. w7418). National bureau of economic research.

Kaminsky, G. L., \& Reinhart, C. M. (1998). Financial crises in Asia and Latin America: Then and now. The American Economic Review, 88(2), 444-448.

Liu, Z., \& Spiegel, M. M. (2013, September). Monetary policy regimes and capital account restrictions in a small open economy. Federal Reserve Bank of San Francisco.

Peters, A. (2009). Exchange rate targeting in an estimated small open economy. University of North Carolina at Chapel Hill. 